\title{
PReS-FINAL-2346: Hypomorphic RAG deficiencies: phenotypic variability and usefulness of TREC/KREC as diagnostic biomarkers
}

\author{
C Schuetz $^{1 *}$, U Pannicke ${ }^{2}$, EM Jacobsen ${ }^{1}$, M Honig $^{1}$, T Niehues ${ }^{3}$, K Schwarz $^{2,4}$, AS Schulz \\ From 20th Pediatric Rheumatology European Society (PReS) Congress \\ Ljubljana, Slovenia. 25-29 September 2013
}

\begin{abstract}
Introduction
An increasing number of patients with combined immunodeficiencies have been found to carry hypomorphic variants of genes that otherwise cause severe combined immunodeficiency (SCID). These patients not only present with recurrent and sometimes life-threatening infections, but also with immunodysregulatory symptoms such as autoimmune cytopenias and granulomas, and are a diagnostic challenge.
\end{abstract}

\section{Objectives}

The objective of this study was to determine whether TRECs and KRECs are useful in identifying patients beyond infancy with combined $\mathrm{T}$ - and B-cell deficiencies who are otherwise difficult to diagnose due to late-onset, heterogeneous clinical phenotypes and variable numbers and functions of $\mathrm{T}$ and $\mathrm{B}$ cells.

\section{Methods}

Patients with combined immunodeficiency due to $h R A G$ mutations $(\mathrm{n}=6)$, with DOCK8 deficiency $(\mathrm{n}=3)$ and with classical SCID due to RAG1, RAG2, ARTEMIS and IL2RG defects were treated at the University Hospital Ulm, Germany. Four of the patients with hRAG deficiencies presented with granulomatous lesions, one with vitiligo, three patients had autoimmune cytopenias. The earliest available samples of MNCs were analyzed (cells cryopreserved at the median age of 10 years, range 6-17 years) for patients with hRAG and DOCK-8 deficiencies.

\section{Results}

Immunophenotyping of hRAG patients' peripheral MNCs showed reduced, but variable numbers of $\mathrm{T}$ and
B cells. Thymic derived naïve $\mathrm{CD}^{+} \mathrm{CD} 45 \mathrm{RA}^{+} \mathrm{T}$ cells were $<30 \%$ in all patients (range 1-27\%). Residual T-cell function (proliferation assays) and B-cell function (antibody titres following vaccination, data not shown) were detectable, but abnormal in all hRAG patients. T-cell repertoires were diverse in 5 patients, and restricted in patients 1 and 4 . Even when detectable, TREC and KREC amounts in hRAG patients were at least 32-fold reduced compared to healthy controls

\section{Conclusion}

Measurement of TREC and KREC levels is a fast and easily performed tool for the quantification of thymic output and B-cell maturation respectively. We envisage that these biomarkers may serve as valuable complementary parameters for the initial immunological work-up when a diagnosis of CID is being considered. Timely clinical suspicion paired with abnormal TREC and KREC levels might facilitate earlier referral of this group of patients with atypical and late presentation of CID to the pediatric immunologist and possibly to treatment by HCT.

\section{Disclosure of interest}

None declared.

\section{Authors' details}

${ }^{1}$ Pediatrics and Adolescent Medicine, UIm University, UIm, Germany.

${ }^{2}$ Institute for Transfusion Medicine, ULM UNIVERSITY, UIm, UIm, Germany. ${ }^{3}$ Center for Pediatric and Adolescent Health, HELIOS Klinikum Krefeld, Krefeld, Ulm, Germany. ${ }^{4}$ Institute for Clinical Transfusion Medicine and

Immunogenetics, Ulm University, Ulm, Germany.

${ }^{1}$ Pediatrics and Adolescent Medicine, UIm University, Ulm, Germany

Full list of author information is available at the end of the article 
Submit your next manuscript to BioMed Central and take full advantage of:

- Convenient online submission

- Thorough peer review

- No space constraints or color figure charges

- Immediate publication on acceptance

- Inclusion in PubMed, CAS, Scopus and Google Scholar

- Research which is freely available for redistribution

Submit your manuscript at www.biomedcentral.com/submit
C Biomed Central 